\title{
Pracht und Prunk der Grosskönige. Das Persische Weltreich. Herausgegeben vom Historischen Museum der Pfalz Speyer, Konrad Theiss Verlag GmbH, Stuttgart, 2006, 260 p., 303 fig.
}

\section{Barbara Kaim}

\section{OpenEdition}

\section{Journals}

Édition électronique

URL : http://journals.openedition.org/abstractairanica/26182

DOI : 10.4000/abstractairanica.26182

ISSN : 1961-960X

Éditeur :

CNRS (UMR 7528 Mondes iraniens et indiens), Éditions de l'IFRI

Édition imprimée

Date de publication : 15 mai 2008

ISSN : 0240-8910

\section{Référence électronique}

Barbara Kaim, «Pracht und Prunk der Grosskönige. Das Persische Weltreich. Herausgegeben vom Historischen Museum der Pfalz Speyer, Konrad Theiss Verlag GmbH, Stuttgart, 2006, 260 p., 303 fig. », Abstracta Iranica [En ligne], Volume 29 | 2008, document 83, mis en ligne le 15 septembre 2008, consulté le 26 septembre 2020. URL : http://journals.openedition.org/abstractairanica/26182 ; DOI : https://doi.org/10.4000/abstractairanica.26182

Ce document a été généré automatiquement le 26 septembre 2020.

Tous droits réservés 


\section{Pracht und Prunk der Grosskönige. Das Persische Weltreich. Herausgegeben vom Historischen Museum der Pfalz Speyer, Konrad Theiss Verlag GmbH, Stuttgart, 2006, 260 p., 303 fig.}

\section{Barbara Kaim}

1 Ce beau livre accompagnait l'exposition organisée sous le même titre par le Musée d'Histoire du Palatinat (Historisches Museum der Pfalz) à Speyer.

2 La publication comporte plusieurs contributions de divers spécialistes : après l'introduction de A. Koch et E. Rehm, J. Wiesehöfer retrace l'histoire de l'empire achéménide, H. Schaudig la prise de Babylone par Cyrus, R. Röllinger présente le problème de la légitimité du pouvoir de Darius, H. Klinkott donne un aperçu de l'organisation satrapique et des pouvoirs des satrapes, B. Weisser discute de l'iconographie du souverain dans la numismatique de la période. Le thème des femmes à la cour royale est abordé par M. Brosius. Deux articles concernent l'architecture palatiale (F. Knauss et B. Jacobs), tandis que deux autres s'attachent aux Perses vus par leurs ennemis grecs (dans l'art et la littérature) et troisième aux Perses dans la Bible. Les objets de luxe font l'objet de trois contributions de H. Dorn et E. Rehm. Ph. Huyse donne une synthèse sur l'écriture vieux-perse et R. Schmitt sur les langues utilisées dans l'empire achéménide.

3 L'ouvrage, édité avec un très grand soin, se termine par une bibliographie citant près de trois cents des travaux les plus importants sur l'époque achéménide. 
INDEX

Thèmes : 3.2.2. Pré-Achéménides et Achéménides

\section{AUTEURS}

BARBARA KAIM

Université de Varsovie 